\title{
TERVEZÉSELMÉLETI ALAPVETÉSEK
}

\author{
(Principals in Regional Planning)
}

\author{
FARAGÓ LÁSZLÓ
}

„A terv semmi, a tervezés minden"

Eisenhower

Jelen munkámban kizárólag a közösségi (public) szférában folyó tervezés néhány elméleti alapkérdését és annak klasszifikálását kisérelem meg. A leirtakban sokat meritettem John Friedmann amerikai professzor munkásságából (Friedmann 1964, 1987, 1988).

\section{A tervezés szükségessége}

A tervezés egy olyan társadalmi kényszer, amely egy történeti tanulási folyamat eredménye. Az elmúlt évszázad igen gyors fejlödése következtében a fejlett társadalmak felismerték, hogy a piaci erök és a magánszféra spontán, parciális érdekeken nyugvó beavatkozásai esetenként vagy összességükben társadalmilag nem kívánatos eredményre vezethetnek, ezért irányitani, kontrollálni kell a folyamatokat. E tevékenységnek fontos, hathatós eszköze a tervezés.

A tervezés szükségességének felismerése és gyakorlati megvalósitása két egymással párhuzamosan futó tradícióra vezethető vissza.

(1) Marx és Engels a 19. századi kapitalizmus ellentmondásainak elemzése alapján arra a következtetésre jutottak, hogy az új gazdasági rend épitése során ex ante szabályozás, azaz tervezés szükséges. E helyes felismerést követően az akkori viszonyokból azt a téves következtetést vonták le, hogy a tervezés során naturáliákban és központilag kell számba venni a forrásokat és a munkaidőalapot. Ebböl számukra logikusan következett, hogy a kapitalista termelési viszonyok között ezt nem lehet megoldani, ezért tervgazdálkodás csak a szocializmusban folyhat. A szocialista tervezési gyakorlat alapelveit Lenin 1921-ben irta meg "Az egységes népgazdasági tervröl" címü cikkében. Ezen tézisek többsége még ma is jól tükrözi a tervezéssel szembeni elvárásokat (a terv a párt második programja, komplexitás, tudományosság, optimalitás, a döntö láncszem elve, a termelés és a jólét összehangolása, tervvariánsok szükségessége, konzisztencia elve, az áru- és pénzviszonyok összehangolása, folyamatos karbantartás elve).

Ludwig Von Mises osztrák polgári közgazdász a szocializmust már 1920-ban a racionális gazdaság megszüntetésével azonositotta. Véleménye szerint nem lehetséges a természetbeni számbavétel és a leggazdaságosabb termelési eljárás ezen alapuló kiválasztása. $F$. A. Hayek szerint a tudományok fejlödésével ugyan elvileg lehetséges a racionális szocialista gazdálkodás, de a gyakorlatban kivitelezhetetlen, mert központilag lehetetlen a racionalitáshoz szükséges tudást és információt biztosítani, ezért decentralizálni kell. 
(2) A kapitalista országokban az állam gazdaságirányítási, tervezési szerepét az $u j$ közgazdasági elméletek alapozták meg. Nyilvánvalóvá vált, hogy a tőkés gazdaság nem tart automatikusan az egyensúlyi állapot felé. Központilag (pl. költségvetési vagy monetáris eszközökkel) meg kell növelni az aggregált keresletet. A valóságos folyamatok elemzéséböl kiindulva J. M. Keynes tett javaslatot az állam szervezö irányitó tevékenységére. Az állami irányitás a kapitalista országokban is közvetlenül átfogja és tervezi a pénz- és hitelpolitikát, a költségvetési politika szféráját (adók, támogatások, állami beruházások, stb.).

Az állam gazdaság-irányítói (tervezöi) szerepe fokozatosan megerösödött. Az 1929-33-as válságból való kilábalás érdekében született a roosvelti New Deal, amely átfogta a pénzügyi szférát, az ipart, a mezögazdaságot, és a szociális szférát. J. Tinbergen 1935-ben megalkotta Hollandia számára az elsö olyan modellt, amelyet olyan makro tervnek tekinthetünk, ami tényleges cselekvési programot adott a kormány számára és indukálta a magánszektor döntéseit. 1946 óta a holland tervhivatal rendszeresen készit éves terveket. 1946-52-re vonatkozóan készült el az elsö indikativ középtávú terv és az ötvenes évek végétöl folyt hosszú távú tervezés is. Közismert a Franciaországban folyó átfogó tervezési munka.

A példák sora folytatható lenne, de általánosságban megállapitható, hogy a második világháborút követöen minden fejlett ország gyakorlata az átfogó gazdaságtervezés és szabályozás irányába folytatódott. Ma már minden fejlett gazdaság egyfajta átfogó gazdasági irányító tevékenység hordozója. A vállalkozási szabadság és a termelési struktúra alakításának, irányitásának összehangolása egyben a terv és a piac együttélését is jelenti.

A tervezés a modern piacgazdaságban:

- többszintü és sokszereplös (a rendszer nem csak a gazdaság alapelemeiböl áll);

- két irányú (egyszerre top-down és bottom-up);

- elfogadja az állami (kívülről, felülröl) beavatkozás szükségességét (a nemzet távlati érdekeit érvényesíti);

- érték-pluralista;

- törekszik megfelelni a társadalmi tudás szintjének (tudományos és racionális), ugyanakkor korlátozza a rendelkezésre álló információ tömege és jellege;

- duális: részben segíti (generálja), részben korlátozza a magánszférát;

- és politikailag meghatározott.

\section{A tervezés fogalma}

Oly hosszú a tudatos előrelátás, a tervezés története, oly széles körủ tevékenységet takar a fogalom, hogy még alig vállalkoztak a szintetizálásra, az általános tervezéselmélet megirására ${ }^{1}$. Egy tömör definíció megalkotása azért is igen nehéz, mert a tervezésnek eltérő módjai, formái és "stílusai" vannak és ma nem egyszer mást értünk alatta, mint korábban. Ennek ellenére nem mondhatunk le az általánosdefiníció alkotás igényéről sem, hiszen minden közösségi tervezési tevékenységben van valami azonos, mindegyik teendöket, cselekvés sorozatokat határoz meg a jövöben bekövetkezö problémák elkerülése vagy a jobb eredmény elérése érdekében. 
A modern közösségi tervezés olyan emberi tevékenység, amely valamely rendszer irányitásának alapja, tehát segíti egy elöre megfontolt szándék kialakitását és az annak alapján való cselekvést egyaránt. Mint módszer jól strukturált, jövöorientált gondolkodásmód. A tudományos és módszertani ismereteket alkalmazzuk a cselekvések megszervezése és megvalósitása érdekében. A tervezés a (tudományos és technikai) tudást cselekvésekké alakítja (Friedmann, 1987).

"A tervezés olyan folyamat, amely során szakemberek a múlt és a jelen megismerése alapján feltárják a föbb tendenciákat, normatív megfontolásokat is figyelembe véve megfogalmazzák a haladás lehetséges irányait, az ezekhez tartozó utakat és elérhető eszközöket, elökészítik az ezekkel kapcsolatos döntéseket és megfogalmazzák a cselekvési programot" (Faragó, 1997, 38. o.).

Operacionalista alapon a tervezést körülírhatjuk azzal a műveletsorral, amelyet e tevékenység során elvégzünk. A tervezési tevékenység általános kereteit az alábbi blokksémával szemléltethetjük.

\section{1. ÁBRA \\ Strukturális blokkséma \\ (Scheme of structural elements)}

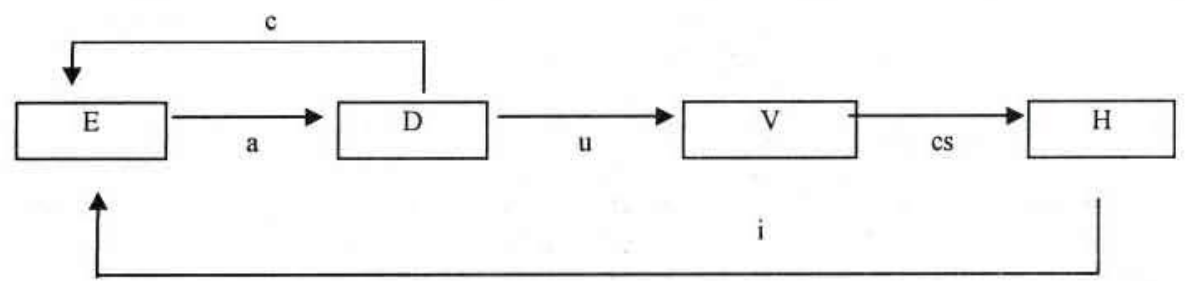

E- elemzés (monitoring)

D - döntéshozatal

c-célok, prioritások normatív korlátok

V - végrehajtás

a-ajánlások (alternatívák)

$\mathrm{H}$ - várt és nemvárt hatások

u - utasítások, intézkedések

cs - cselekvések, akciók

i - információk

Forrás: Friedmann 1987. 181. o. nyomán a szerző

E folyamatba tartozó tevékenységek mindegyike nem minden esetben a szüken vett tervezés része és a tervezök szerepe is attól függ, hogy milyen típusú és stilusú tervezésröl van szó (lásd késöbb). A tervezés általában az alábbi müveletsor elvégzését jelenti:

1. Vizsgálat / diagnózis (audit)

2. Koncepcionálás: • koncepció (jövökép és célok)

- stratégiai program

3. Cselekvési terv (operatív programok)

4. Végrehajtás

5. Kontroll (monitoring) 


\section{A tervezés politikai karaktere ${ }^{2}$}

Gondolom, nem szorul magyarázatra az a tény, hogy a „szocialista pártállami” rendszerben a tervezés az egyeduralkodó pártpolitikának alávetetten tudott csak müködni, így a célmeghatározásban alig játszott szerepet, a végrehajtás bürokratikus, merev eszköze volt. Ugyanakkor joggal merülhet fel a kérdés, hogy a polgári demokráciában, a piacgazdaság körülményei között a tervezés politikailag meghatározott-e, vagy azon kollégáimnak van igazuk, akik a tervezés objektivitását, szakracionális jellegét hangsúlyozzák.

A mai pragmatikus tervezés politikailag érzékenyebb és kevésbé "racionális", mint az korábban volt. Változtak a tervezéssel szembeni elvárások. A tervezés feladata egyre inkább konszenzus kialakitása, a tárgyalási, az alku folyamatok moderálása, melynek hatékony teljesitése elképzelhetetlen anélkül, hogy a tervező azonosulna a megbizó alapvetó értékeivel. A tervezötöl gyakran explicite is megkívánják, hogy támogassa a megrendelő törekvéseit és a megbízásnál fontos szerepet játszhat a tervező érdek artikuláló, lobbyzó képessége.

A döntések tudatos értékválasztáson alapulnak, amelyek mögött minden esetben érdekek húzódnak meg. A különbözö szintek és szereplök mást és másokat képviselnek. Az állam meghatározott preferenciák alapján avatkozik be, egyeseket korlátoz, másokat támogat. A politika elfogadhatja az „objektív tudást” vagy időlegesen nem vesz róla tudomást, ez esetben az, más csatornákon éppen az uralkodó politika ellen is felhasználhatóvá válik.

A tervezési folyamat egyes mozzanataiból megpróbálhatjuk távol tartani a politikát, de az egész folyamat, ha akarjuk, ha nem imlicite átpolitizálódik ${ }^{3}$. A források allokálása, a beruházások rangsorolása, új struktúrák létrehozása mind értékválasztáson alapuló döntést igényel! A közösségi szférában a dőntések jelentös részét a „közérdekre” hivatkozva hozzák meg. De mit jelent a közérdek (közjó) egy képviseleti demokráciában? A közérdek a napi gyakorlatban nem más, mint a pillanatnyi politikai konszenzus, vagy rosszabb esetben a „többség akarata” a kisebbséggel szemben.

Fontosnak tartom hangsúlyozni, hogy amikor a tervezés politikai karakteréröl írok, akkor ide nem csak a politikai pártok és korporációk által uralt szférában folyó tervezést sorolom. A társadalmi mozgalmak, az NGO-k által folytatott tevékenység (pl. zöldek) éppen úgy nem mentes a politikától, csak az ö szándékaik más értékeken nyugszanak és más típusú a felelösségük ${ }^{4}$.

Ez alól nem kivételek a területi mozgalmak sem, de természetesen ez nem osztály vagy réteg politizálást jelent. Ebben az esetben az egyén tudata nem, mint a nemzet, az osztály vagy valamely makroközösség része "funkcionál", hanem mint az adott területi egység lakójáé, és meghatározó momentum a területi identitás. A területileg elkülönülö népesség (regionális, helyi társadalom), mint "kis társadalom" a területi érdekeket képviseli. A tér elkülönít, de ebben az esetben integrál is, felértékelödnek a helyi adottságok és speciális helyi preferenciák.

$\mathrm{Az}$ allokatív tervezés esetében, így pl. a várostervezésben és a rendezési tervezés folyamatában mód van arra, hogy "a tényeket és az értékeket" " megkülönböztessék egymástól. Erre lehetőséget kínál, hogy az értékválasztás (célok megfogalmazása) és az ezen alapuló döntések elkülönülnek a tervezési folyamattól. Mint késöbb látni fogjuk, ez a „szerencsés” helyzet nem minden tervezési típusnál (módnál) van így. 


\section{A tervezés alaptípusai}

A közösségi tervezés alaptípusai; az allokatív, az innovativ és a radikális tervezés. $\mathrm{Az}$ eltérö típusú tervezési folyamatok (a mögöttes „érdekcsoportok") gyakran konfliktusba kerülhetnek egymással. Például a hagyományos tervezés allokativ szemlélete ütközhet a fejlődést, a változást akarók csoportjával, különösen, ha ök alapvető strukturális változtatásokat céloznak meg. Ugyanakkor nem helyes valamelyiket általában pozitívnak, haladónak beállitani, és szembe helyezni a másikkal, mert mindegyikre szükség lehet, konkrét esetekben egymással nem is helyettesithetök.

\section{a) Allokatív tervezés}

Az allokatív tervezés a korlátozottan rendelkezésre álló forrásokat igyekszik elosztani az egymással versenyző fejlesztési szükségletek vagy felhasználók között. Ez a tervezés tradicionális funkciója és még ma is a leggyakrabban használatos forma (pl. a központi újraelosztás erre a logikára épül). A fennálló rendszer, a meglévő struktúra keretei között igyekszik a minél hatékonyabb, méltányosabb vagy éppen az egyensúlyt, a "társadalmi békét" szolgáló megoldást megtalálni. A dőntéshozók ellátják a tervezöket célokkal és prioritásokkal, a tervezök pedig a fennálló korlátok között javaslatot tesznek a konkrét teendökre. Az allokatív tervezés tipikus példája a költségvetési tervezés, a fizikai tervezés (a területfelhasználás szabályozása) és általában a központi ágazati tervezés.

Az allokatív tervezés fö jellemzöi:

- el(fel)osztó jelleg: a tervezés tárgyának az adott szereplök, feladatok vagy funkciók közötti elosztása;

- funkcionális racionalitás: azon feltételezésen alapul, hogy az információ beszerezhetőségének korlátai között racionális döntések hozhatók és a döntéshozók tudatos értékválasztása, a tervezés során alkalmazott racionalitás, egymástól elválasztható és fúggetlen. Azaz a tervezök tudományos alapokon - a megadott keretek között - racionálisan cselekszenek és a képviseleti demokráciában a döntéshozók a „közjót” képviselik;

- komplexitás, széleskörüség: törekedni kell arra, hogy minden kapcsolódó területre kiterjedjen a tervezök figyelme;

- egyensúly: a rendszer különböző elemei között az egyensúlyt meg kell tartani, illetve helyre kell állítani;

- mennyiségi szemlélet: a tervezés során, modelleken kell ellenörizni a javasolt megoldások helyességét (input-output, szimulációs, lineáris és dinamikus programozási stb. modellek).

$\mathrm{Az}$ allokatív tervezés három szereplöje a döntéshozó (politikus, megrendelö), a tervezö (vállalkozó vagy bürokrata) és a bürokrácia (végrehajtó). Funkcióik jól elkülönülnek:

- a politikusok célokat határoznak meg és választanak a lehetséges alternatívákból,

- a tervezók elemeznek, alternatívákat dolgoznak ki, és javaslatokat tesznek,

- a bürokraták informálnak, végrehajtanak, ellenöriznek. 
A folyamat optimális lefolyását többek között korlátozhatja a döntéshozó hatalmi törekvése, a tervező szakmai sovinizmusa és a bürokrácia konfliktus elkerülési hajlama.

Az allokatív tervezés egyik kritikus pontja a döntéshozatal. A döntésekkel kapcsolatban sok a félreértés. Tisztázandó, hogy ki és mikor hozza a döntéseket. Az allokatív tervezés során az alábbi típusú döntések hozandók:

1. Szakmai feladatot jelentő tervezôi döntések. A tervezö feladata meghatározni a szükséges információk és a tervezésben résztvevök körét, megválasztani a tervezési módszert, modellt választani, stb. A döntések a tervezés folyamatában születnek és a tervezök hozzák azokat.

2. Tervdöntéseknek nevezem azokat az érdemi döntéseket, amelyek a célokkal, prioritásokkal, tervvariánsokkal és a végleges terv elfogadásával kapcsolatban születnek. Ez is a tervezési folyamaton belül van, de a tervezés szük körén kivül születik. A döntést hozó lehet szakmai-, politikai testület, egy népesség csoport vagy választott képviselöik, stb., de nem a gyakorlati tervezó munkát végzók.

3. A terv végrehajtása során hozandó döntések. A tervezési munkafázist követik, és általában nem a tervezök feladata. Egy részük, amely a végrehajtással, annak ellenörzésével kapcsolatos a bürokrácia feladata (monitoring), de amennyiben a körülmények lényegi kérdések megváltoztatását vetik fel, vissza kell vinni a kérdést az eredeti döntéshozóhoz (kontroll).

Az allokatív tervezés folyamata:

$\checkmark \quad$ a feladat pontos meghatározása (alapvetö célok prioritások);

- vizsgálat: adatok, információk gyüjtése, elemzése, prognosztizálás;

- koncepcionálás (stratégiai program)

- döntéselökészités;

$\checkmark$ döntéshozatal;

- alternatív lehetöségek és cselekvéssorozatok kimunkálása (operatív programok);

- döntéselökészités;

$\checkmark$ döntéshozatal;

* végrehajtás;

* monitoring;

$0 \quad *$ kontroll.

- - tervezói feladat

- - politikusi, döntéshozói, megrendelöi feladat

* - bürokrácia feladata

\section{b) Innovatív (fejlesztés-orientált) tervezés}

A haladás és a valódi problémamegoldás innovatív, fejlesztés-orientált megközelítést igényel. Az innovatív tervezés az allokatívval szemben nem a már meglévő vagy a fennálló trendekböl eredö források elosztására, hanem fejlesztésekre, a jelen meghaladására ${ }^{8}$ irányul. Annak érdekében, hogy a tervezök el tudják fogadtatni az új innovációkat, az irányitási rendszer egészére nagyobb befolyást kell gyakorolniuk. Vagy közvetlen részeseivé kell, hogy váljanak a döntéshozatalnak, vagy meg kell szerezniük a politika támogatását. 
$\mathrm{Az}$ innovatív tervezés esetében nem annyira az apparátusok bürokratikus ismeretei a fontosak, hanem sokkal inkább a vállalkozói képességek és az innovációkra való fogékonyság.

Az innovatív tervezés jellemzöi:

- fejlesztés-orientáció: a fennálló rend alapstruktúráján belül fejlesztések, innovációk kidolgozása;

- intézményrendszer változtatása: az új értékek és javaslatok általában az új funkció és hatáskör megosztást tételezik fel, azaz új intézmények szükségesek;

- cselekvés-orientáció: a célok és megvalósitásuk elválaszthatatlan egységet alkotnak, ami esetenként a döntésekre és a megvalósításra való nagyobb hatásgyakorlást igényel;

- eröforrás mobilizáció: a tervezö vállalkozói funkciót teljesit, amikor az új feladatokhoz, intézményekhez erőforrásokat kutat fel, a megvalósítás újszerü formáit kínálja. A döntéshozókkal csak akkor lehet elfogadtatni egy meröben új megoldást, ha meg tudjuk mondani, hogy ki, miböl és mit fog csinálni.

Az innovativ tervezés és döntéshozatal folyamata:

1. A tervezés szükségességének a felismerése és a feladat pontos megfogalmazása; (Kezdeményezö lehet a tervezö is!)

2. Társadalmi, minőségi szempontok feltárása:

* a problémáknak nem mint mennyiségi kérdéseknek, hanem mint társadalmi-gazdasági jelenségeknek az azonositása és leírása;

* az aktorok érdekeinek, viselkedésének az elemzése (autonómia mértéke, legitimáltsága, müködésének hatékonysága, fogékonysága az innovációkra, stb.);

* az „intézmények viszonya" az irányitási-, döntési rendszerekhez. (Hierarchiában elfoglalt hely, részvételi lehetőségek a döntési folyamatokban, információáramlás, szervezeti kapcsolatok.);

3. Preferenciák megfogalmazása és a célok kijelölése;

4. Az innovációra és az innovatív cselekedetekre lehetséges variánsok vagy alternatívák kidolgozása;

5. A döntéshozó meghatározása és külsö döntéshozatal vagy részvétel a döntéshozatalban;

6. A megvalósítás, illetve a döntés érvényesítés figyelemmel kísérése.

\section{c) Radikális tervezés}

Marx írja Tézisek Feuerbachoz c. munkájában (1844), hogy a filozófusok kủlönbözöképpen interpretálják a világot, a lényeg annak megváltoztatása. Ez ars poeticaja lehet a radikális tervezésnek. Tapasztalati tény, hogy mély (strukturális) válságból nem lehet visszatérni az azt megelözö állapotba, hanem alapvető (radikális) változtatásokra van szükség. Valakiknek fel kell vállalniuk, hogy az állampolgárokat a társadalmi átalakulás irányába mutató projektek mögé állitsák. A radikális tervezés egy olyan cselekvés-sorozat, amely a társadalomi-gazdasági rend uralkodó trendjeivel szemben kezdeményez alapvetổ strukturális változásokat, és igy kívánja átalakitani a korábbi folyamatok jellegét. Segítségével olyan új struktúrák, cselekvések alakithatók ki, melyek nem az uralkodó trendek folytatása. 
A radikális tervezés igényli a tervkészités, a dōntéshozatal és végrehajtás fúzióját. A tervezō egy akcióteam tagja. A radikális tervezés független az uralkodó struktuira döntéshozási mechanizmusától. A tervezō (-team) egyben programalkotó és végrehajtó is, maga szerzi és használja fel a forrásokat és törekszik saját hatalma kiterjesztésére és befolyásának növelésére. A tervezö a hivatalos (állami) szférán kivül müködik. Ma a leggyakrabban előforduló példák a cselekvés-orientált társadalmi mozgalmak.

A radikális tervezés győkerei visszanyúlnak az utópista, a marxista és az anarhista tradíciókhoz. Radikális tervezés a megállapodott demokráciákban is van, de általában csak a társadalmi-gazdasági lét egyes részteruleteire terjed ki. Ide sorolható számos szocio-politikai mozgalom és alternatív gazdasági törekvés. Például kapitalista körülmények között a szövetkezeti mozgalom, vagy a kommunista Kínában a különleges gazdasági övezetek beindítása, számos feminista és zöld mozgalom, és még folytathatnánk a sort.

A kliens ebben az esetben nyilván nem egy „külső megrendelő”, hanem maga a kezdeményezô, illetve a mobilizált csoport. A projekt pedig a fennálló rend vagy valamelyik alrendszerének a megváltoztatása.

A radikális tervezés jellemzöi:

- transzformatív elméletre épül;

- önfelhatalmazás és őnszerveződés;

- határok, korlátok nélküli gondolkodás;

- kapcsolat épités, hálózatok szervezése;

- dialógus, kölcsönös tanulási folyamat.

A radikális tervezés folyamata:

1. A "fennálló rend", az adott gyakorlat (vagy bevett szokások) kritikája.

2. Alternatív javaslat kidolgozása.

3. Cselekvési stratégia és taktika kidolgozása.

4. "Ismeretek" terjesztése, szövetségesek keresése.

5. Összeütközés a fennálló renddel, a meglévő intézményekkel.

6. Terjeszkedés (siker esetén). 
A tervezés alaptípusainak jellemzói

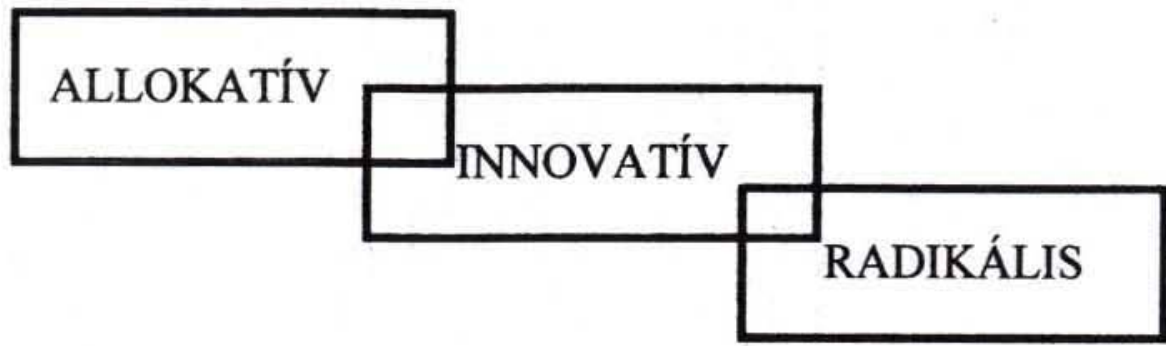

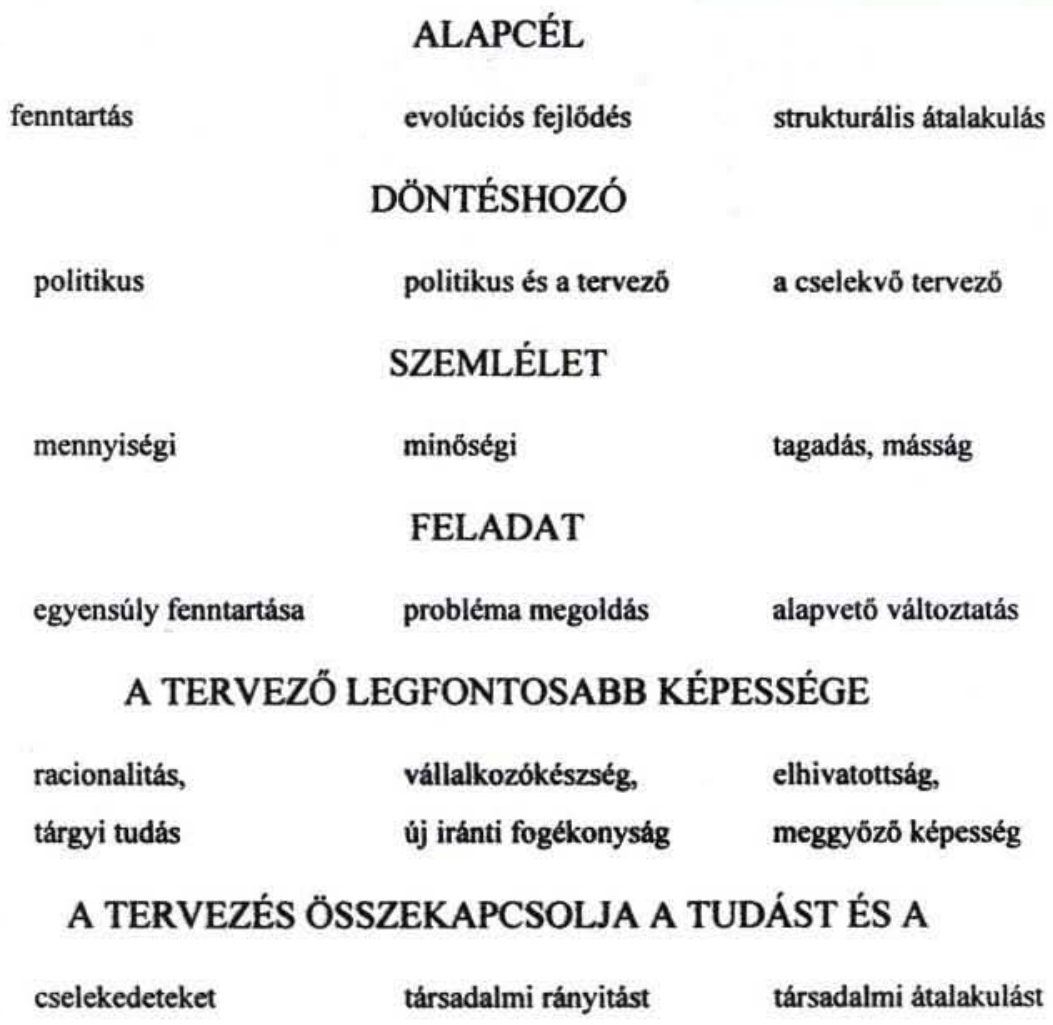

A TERVEZŐ POLITIKAI FELELÖSSÉGE

"csak" szakmai felelőség kőzepes nagy

\section{A TERVEZÖI MUNKA INDÍTÁSA ÉS IDŐTARTAMA}

megbízás, eseti

folyamatos

önfelhatalmazás, eredményfüggő 


\section{Tervezési stilusok}

A tervezés stílusát alapvetöen a tervezésnek az irányitási rendszerben elfoglalt helye határozza meg, amely függ a centralizáció (decentralizáció) mértékétöl, az alkalmazott eszközök jellegétöl (közvetlen - közvetett) és a tervező szándékától.

Tervutasitás: a terv minden.

Az imperatív tervezés a szovjet típusú rendszerek jellemzöje. Erösen centralizált és intervencionalista, kötelezö célok és normák képezik a tervek alapját. A tervek konkrét, a részleteket is tartalmazó cselekvési programokat adnak, amelyeket politikailag elkötelezett specialisták és bürokraták készitenek. A tervezést és végrehajtást központilag ellenörzik és szankcionálják. A tervek egymással hierarchikus kapcsolatban állnak és a magasabb szintüek kötelezöek az alacsonyabb szintek számára. A tervezési jogosultságot meghatározott szervezetekhez kötik.

Stratégiai tervezés (policies planning) ${ }^{9}$ : a terv indikáció.

Célja - a saját programalkotáson kívül - mások cselekedeteinek nem kötelezö jellegü szabályozása, indirekt befolyásolása. Felsöbb szinteken a rendszer müködtetésének általános szabályait alakítják ki. A föbb sarokpontok betartása mellett az alacsonyabb szintek szabadon alakíthatják saját programjukat. Közvetett eszközökkel kívánják a társadalmi-gazdasági szereplöket befolyásolni. A direkt irányitás és beavatkozás csak a kulcsterületeken engedhető meg. Strukturált döntési mechanizmus müködik. A tervezöi bürokrácián kívüli szakemberek is kaphatnak tervezöi jogosultságot. A tervezők gyakran, mint tanácsadók müködnek, így közvetlenül részt vesznek a politika alakításában.

Korporativ tervezés: korporációk közötti egyeztetés.

A hatalom és a döntések megoszlanak kis számú intézmény és szervezet között. A kompetenciák jól elkülönülnek, a szervezeti rendszer hierarchikusan strukturált. Tárgyalások, iterációk során alakulnak ki a célok. A kormányzati szerveken kivül a hatalom egyéb részesei viszonylag függetlenül tervezhetnek. $\mathrm{Az}$ egyes szempontokat külön tervezik, majd az eredményeket ütköztetik. Az egyezségek hatalmi-politikai játékok, ami forditva is igaz, a politika-csinálás egyfajta tervezési folyamat. A résztvevőknek gyakran vétójoga van a saját területüket érintö negatív döntések esetén. A programalakitásban, a hatalomban résztvevök a meglévö struktúra fenntartásában érdekeltek.

Széles részvételen alapuló tervezés: széleskörü konszenzus kialakításának az eszköze.

Minden érintettet igyekeznek bevonni a tervkészités folyamatába. Ez elsősorban olyankor fordul elö, amikor a végrehajtás decentralizált és a programot megvalósítók megnyerése a megvalósitás záloga. A közösségek, társadalmi szervezetek is részt vesznek a tervezési folyamatban. A résztvevök önként vállalnak kötelezettséget a források biztositására és a feladatok ellátására. A tervezési folyamat középpontjában a tárgyalások folyamata, az érdekegyeztetések, a konfliktusok feltárása és feloldása áll. A tervezés menete, struktúrája a problémákhoz, a folyamatokhoz idomul, társadalmilag alakul, és nem a központi 
bürokrácia „találja ki". A társadalmi szervezetek maguk is hozzájárulnak a programok megvalósitásához. A központi hatóságok szerepe korlátozott, az információ átadás és technikai segitség a döntő eleme. Tervezési szakemberekre ebben az esetben is szükség van, de ök nem csak a központi bürokrácia alkalmazottjai, hanem független (helyi) szakemberek is lehetnek.

Tranzaktiv tervezés: a kommunikáció fóruma, kölcsönös tanulási folyamat.

A tranzaktív tervezés a tudást új ismeretekké, megváltozott szemléletté alakítja folyamatos személyes kapcsolatok során, amely közvetve hat a cselekedetekre. Ez ritkábban allokatív, inkább innovativ és radikális tervezést jelent. Elsősorban a döntéshozók (tervezök) és klienseik között lévö kommunikációs szakadék áthidalására szolgál. Intézmények esetében lényegi kérdés, hogy ki(k) a partnerei a tervezöknek. A tervezö e folyamatba beviszi az elméleti tudást, a módszertant, koncepciót, szisztematikus munkát. A kliens a prioritásait, céljait, a realitás érzékét az alternatívák közötti választáshoz, a szükebb, nem publikus információkat a konkrét körülményekröl, a megvalósítás részletkérdéseit viszi a folyamatba.

\section{A területi tervezés helye e struktúrában}

A magyar gyakorlatnak megfelelően alapvetően két klasszifikációt kell „besorolnunk":

- fejlesztési és rendezési típusú terveket,

- a különbözö szinteken folyó tervezést.

Ezekre külön-külön minden komplikáció nélkül elvégezhetnénk az allokatív, innovativ és radikális tervezési besorolást, de ha ezeket együtt, a maguk komplexitásában nézzük, akkor egy sajátos ellentmondást tapasztalunk. A fejlesztési tervezés innovatív, esetleg radikális szemléletü kell, hogy legyen, míg a rendezési tervezés $a b$ ovo allokativ típusú. Ugyanakkor minél magasabb területi szinten folyik a tervezés, annál kevesebb a konkrét rendezési-tervezési feladat és annál inkább fejlesztési típusúnak kellene lennie az ott folyó tervezöi munkának. (2. ábra) Ugyanakkor a magasabb szinteknek eo ipso van egy (re)disztributiv, egyensúlyt fenntartó - területi szempontból rosszul értelmezve - kiegyenlítö funkciója, azaz allokatív. Ez az ellentmondás valós, de nem feloldhatatlan.

Az új innovációk térben pontszerüen, azaz a hierarchikus szinteknek megfelelöen, helyben keletkeznek. Egy alulról építkezö, nem túlszabályozott, hanem inkább indikatív megengedö tervezési rendszerben a felsőbb szintek "felkarolják" az elismert, bevált, azaz a struktúrába integrálódni képes, érdekeiket szolgáló újdonságokat és ezek térbeli terjedését elösegitik. Ez éppen az allokatív és az innovatív tervezés határmezsgyéjén van. A tervezö nem vett részt a fejlesztésben, új intézmény kidolgozásában, de országosan intézményesítheti azt.

A nálunk újra megerösödni látszó, fentröl lebontó rendszerben az allokatív szemlélet dominanciája miatt nem tud az innovativ típusú tervezés eredményeket felmutatni, így szükségszerüvé válhat a radikális tervezés megjelenése. 


\section{2. ÁBRA}

A rendezési és fejlesztési tervezési feladatok megoszlása szintenként

(Planning competence at distinct levels of decision making)

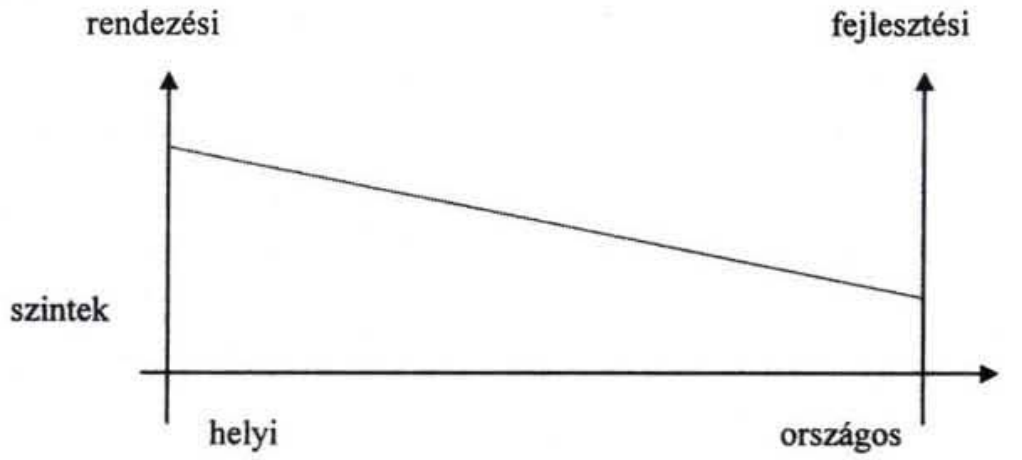

\section{A növekvő bizonytalanság kezelése}

A tervezés felkészülés a jövốre. A mai ismereteink alapján kivánunk cselekvési programot adni a jövő számára, így számolnunk kell a bizonytalansági tényezókkel. Megalapozott a hagyományos tervezéssel szemben felhozott azon kétség, miszerint a mai ismereteink alapján nem ismerjük a jövő generációjának preferenciarendszerét. A saját célstruktúránk is változik és majdnem biztos, hogy nem azonos a kővetkezö generációk elképzelésével.

Mi ebben az esetben a teendő? Természetesen nem a tervezés elvetése, hanem:

- Korszerü technikát, modelleket kell alkalmazni.

- Az összefüggéseket nem determinisztikusan kell értelmezni és kezelni, hanem sztochasztikusan.

- Növelni kell az alternatívák számát.

- Szükség esetén nem konkrét tennivalókat, hanem megoldási algoritmusokat kell kidolgozni.

- Elfeledhetjük a klasszikus alapképletet, miszerint felvázoljuk a jövö ideálképét, majd az azok eléréséhez vezető utakat, és ezek alapján allokáljuk a jelenleg ismert és elfogadott eszközöket. Nem a célokból, hanem az adottságokból kell kiindulni. Szélesebb körben kell alkalmazni a „step by step" módszert.

- Az állapot-tervezésröl a hangsúlyt a folyamat-tervezésre kell helyezni.

- A blue-print típusú tervezéssel szemben a folyamatos tervezés, a tervek folyamatos karbantartásának gyakorlatát kell bevezetni.

- A fenntartható fejlödés/társadalom elvének az érvényesitése. A saját tevékenységünket úgy kell megtervezni, hogy az ne jelentsen abszolút korlátot a jövő generációi számára. Ebböl következnek a természet megóvásának követelményei, a nem megújítható természeti eröforrásokkal való takarékoskodás és a megújítható energiaforrások használatának növelése. 
Hibás felfogás, hogy az a jó terv, amelyik megvalósul. Jó, ha nem következnek be olyan események, amelyek meghiúsítják egy elképzelés megvalósulását. De önmagában az a tény, hogy egy tervet változtatni kell, karban kell tartani, visszamenöleg nem minösíti a tervezök tevékenységét. Hibás, ha nem vettek számba elöre látható dolgokat, külső összefüggéseket, nem éltek a tudomány legújabb vivmányaival. De nem mindig ez a helyzet. Az élet, a társadalmi folyamatok bonyolultsága, komplexitása nem teszi lehetővé, hogy a tervező minden összefưggést feltárjon. Az információk szükössége, beszerzésük költségei, az egyén, a csoport szubjektív korlátai, a modellezés, az absztrahálás, a valóság szükséges sematizálása objektiv korlátokat jelent a tervezésben.

\section{A tervezési tevékenység dokumentumai}

E fogalmakat - nem ritkán - egymás szinonimájaként használjuk.

- jövőkép: értelmezése kettős:

a) olyan nagy távlatra szóló állapot-ábrázolás, amely elsősorban a célrendszer megfogalmazásában lehet segitségünkre, igy a koncepció készitését alapozza meg és ezért a vizsgálati fázisba tartozik;

b) az elérni kivánt jővő leírása, - az angol szakirodalomban „vision” - így a koncepció meghatározó része;

- prognózis: fejlödési törvényszerüségek „mechanikus” elöre vetitése, a föbb trendek meghatározása;

- forgatókönyv: a valószínüségi alapon bekövetkezö jövökép, amely korlátozott számú bizonytalansági tényezöt is kezel;

- koncepció/stratégiai program: koherens fejlesztési elképzelések, lehetöségek megfogalmazása, amely a célmeghatározás tekintetében érdekegyeztetési, koordinációs feladatokat tölt be és orientálja a különbözö döntéshozókat, és nem keletkeztet jogokat és kötelezettségeket a többi jogalany számára;

- fejlesztési/operativ program: konkrét feladatok (akciók) megfogalmazása, eszközökkel, a végrehajtásért felelősőkkel, határidőkkel együtt;

- terv: minden részletében kidolgozott, jóváhagyott fejlesztési program, amely kötelezettséget jelent a végrehajtók számára.

Az előzőekben leirtaktól a stratégia eltérö értelmezésével is találkozhatunk. Az egyik nézetcsoport a stratégiát az elöre megfontolt cselekvések olyan átfogó keretének tartja, amelynek egymást követö részelemei a fejlesztési koncepció, program és a különbözö projektek. A területfejlesztésröl és -rendezésröl szóló törvény a stratégiát a fejlesztési program részének tekinti. A ,stratégiai program” a potenciális aktorok szándékainak és forrásoknak az összehangolása, egy olyan „keret”, amelyen belül a konkrét megoldások keresendök. 


\section{A tervek időhorizontja}

A tervek időhorizontjának mindig a tervezendö folyamat jellegéhez kell igazodnia. Kivétel lehet, amikor egy adott döntéshozó csoport számára ad programot, ilyenkor például választási ciklusokhoz is köthetök az idöhorizontok.

Általában a múltba olyan messze kell visszatekinteni, amilyen távlatokban elöre szeretnénk gondolkodni. Kivételt képez, ha olyan törés van az adatsorban, ami a vizsgálandó adatok összehasonlíthatóságát megkérdöjelezi. (pl. a háború elötti utolsó békeévet kell figyelembe venni egy növekedési, ellátási, stb., összehasonlitásnál, és nem az első békeévek valamelyikét. Nem lenne helyes az sem, ha pl. a légszennyezés mérséklődését az 1990-es adatokhoz képest határoznák meg.) Módszertani kérdés, hogyan lehet az adatokat összehasonlíthatóvá tenni, a töréspontokat felismerni, stb.

Minél nagyobb távlatban gondolunk elöre, a múlt és a jelen determinisztikus hatása annál kevésbé érvényesül, döntési szabadságfokunk nö, és annál aggregáltabban kell a tényezőket figyelembe vennünk. Az aggregáció fokozása megvéd a részletekben rejlő bizonytalanságokkal szemben, de éppen ezért nem tudunk a részletekről semmit mondani, így nehéz erre programot épiteni. A lehetséges jövőváltozatok közül ki kell választani a kívánatos és az elkerülendö változatokat. Nem elég csak a kívánatos jövő elérése érdekében programot kidolgozni, fontos annak meghatározása is, hogy a nemkívánatos jelenségek bekövetkezését elkerüljük.

Az időhorizont alapján a tervdokumentumok készülhetnek:

- Nagy távlatra (15-30 év): erre az idöhorizontra nem készíthetöek tervek, csak jövőképek és forgatókönyvek.

- Hosszú távra (8-15 év): ezek a fejlödés föbb tendenciáival, a fejlödés föbb irányaival foglalkoznak. Jelentös feladatuk van a fejlesztési irányok összehangolásában. Felvázolják a szükséges és lehetséges teendöket. Speciális, hosszú távú feladatokhoz részletesebb programot is adhat, de nem ad konkrét mértékeket. Ezekben kell meghatároznunk a főbb strukturális változásokat. Ez a fejlesztési koncepciók, stratégiai programok tipikus időhorizontja.

- Közép távra (3-7 év): a fejlesztés föbb arányait, a mértékeket határozza meg. Ez nem egyszerüen a hosszú távú tervek időarányos bontása. Szubjektív véleményem szerint a tervezhetőség szempontjából ez a legfontosabb idöhorizont. Az elörelátás hibahatárai még elfogadhatóak, és a cselekvéseink hatásai már kézzelfoghatóan jelentkezhetnek. A fejlesztési/operativ programok tipikus időhorizontja.

- Rövid távra (pár hónaptól 3 évig): konkrét intézkedéseket, teendöket fogalmaz meg. Konkrét cselekvési program a szükséges eszközökkel, a végrehajtásért felelösek megnevezésével, stb. A döntési szabadságfok kicsi, múltbeli döntéseink eredményeinek vagy éppen eredménytelenségének, következményeinek hatása erősebb. 


\section{Jegyzetek}

${ }^{1}$ E téren kiemelkedő Andreas Faludi és John Friedmann munkássága. Lásd: irodalomjegyzék.

${ }^{2} \mathrm{E}$ felvetés helyességét igazolja más oldalról Lukovics T. 1997. cikkében.

${ }^{3}$ Természetesen itt nem a pártpolitizálásról, a pártok és politikusok sajátos (választási) érdekeiröl van elsősorban szó, habár olykor ennek figyelmem kivual hagyása is veszélyekkel járhat.

4 Ez annak ellenére így van, hogy gyakran a politikamentességet, a társadalmi, népi jelleget hangsúlyozzák.

5 "A várostervezöket figyelmeztetni kell, hogy a tényeket és az értékeket megkülönböztessék munkájuk során." - interjú Denise Scott Brownnal Falu-város-régió 3. évf. 8-9. sz, 3-6. o.

${ }^{6}$ Ezt néha szabályozási (regulatory) tervezésnek is nevezik.

7 Jogi értelemben a tervezöi jogusultságot és a tervkészitési jogositvánnyal rendelkezöt (döntéshozót) kell megkülönbőztetni, de én itt konkrétan a tervezési müveletek végzőit értem tervezön.

${ }^{8}$ "....amikor egy elképzelés konvencionálissá válik ideje újragondolni azt!" (Clarence Stein)

${ }^{9}$ A stratégiai tervezés bevezetése tőbb kapitalista országban kezdetben a kőzpontositás, az állami hatalom kiterjesztésének az eszkőze volt, majd később a dekoncentrációt segítette. Nálunk segithetné egy decentralizált tervezési rendszer kiépitését és mükődését.

\section{Irodalom}

Clavel P., j. Forester és W. W. Goldsmith (1980) Urban and Regional Planning in an Age of Austerity. Oxford: Pergamon Press

Faludi A. (1973) Planning Theory. Oxford: Pergamon Press

Faragó L. (1997) Szempontok a teruletfejlesztési tanácsok tervezési gyakorlatához. Comitatus VII. évf. 38-44. 0 .

Friedmann J. (1964) Regional Planning as a Field of Study. In: Friedmann, J és W. Alonso (szerk.) Regional Development and Planning. A reader. Cambridge: The M.I.T. Press

Friedmann J. (1987) Planning in the Public Domain. New Jersey: Princeton University Peress

Friedmann J. (1988) The Politics of Place: Toward a political Economy of Territorial Planning. In: Higgins, B. és D.J. Savaie (szerk.) Regional Economic Development: Essayes in Honour of Francais Perroux, Boston: Unwin Hyman.

Lukovich T. (1997) Mindig meglep. Urbanisztika, 4. évf. 2. sz. 1-2, o.

\section{PRINCIPALS IN REGIONAL PLANNING}

\section{LÁSZLÓ FARAGÓ}

Fundamental theoretical approaches of regional planning are discussed in the study that are based chiefly on J. Friedmann's approach. Establishment and recognition of the need for modern spatial planning are discussed in terms of "socialist" (centrally planned) and market-based traditions.

Planning is defined by the author as the analysis of main trends of the past and the future, specification of main directions of the future development and the range of devices required to reach them, arrangement of decisions and formulation of the action program furthermore, political content of the process must be pointed out as well.

Three types of planning (the allocative, innovative and the radical one) are discussed in details. The author distinct five "manners" of planning according to their position in the planning system such as centralised, strategic, corporative and transactional planning furthermore, planning supported by social activity. In the last chapter, regional planning is put into the context of the structures described above. 